Received: 16-01-2019 | Revision: 16-04-2019 | Accepted: 13-12-2019

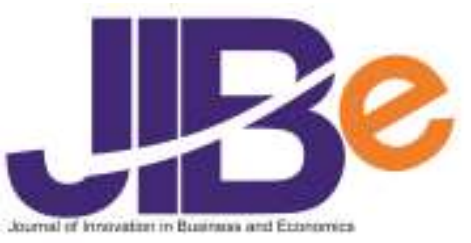

\title{
Model of Islamic Wealth Management Based on Maqasid al-Shariah
}

Isma Swadjaja ${ }^{1}$, Tjiptohadi Sawarjuwono ${ }^{2}$, Unti Ludigdo ${ }^{3}$

\author{
Postgraduate School of Islamic Economics, Universitas \\ Airlangga, Indonesia; Department of Masters in Sharia \\ Economic Law, Universitas Muhammadiyah Surabaya, \\ Indonesia ${ }^{1}$ \\ Accounting Department, Universitas Airlangga, Indonesia ${ }^{2}$ \\ Accounting Department, Universitas Brawijaya, Indonesia ${ }^{3,}$
}

DOI: https://doi.org/10.22219/jibe.v3i02.7465

\begin{abstract}
Islamic wealth management has been aimed at choosing investment instruments so that their portfolios get maximum returns. The process of wealth management emphasizes wealth accumulation without linking it with Maqashid alShariah, such as how to safeguard assets (hifz al-mal), protecting assets oriented to offspring (hifz al-nasl) and so on. The orientation is on welfare in the world without involving elements of blessing and the pleasure of Allah SWT. This study uses a qualitative method through the postmodernism approach. First, the reconstruction of the model is associated with relevant values in Maqashid al-Shariah. Second, the researcher makes observations on the actions and thoughts of investors in interpreting investment and managing investment returns by shariah in the capital market. Third, applying the Islamic wealth management model based on Maqashid al-Shariah according to the results of the study. The output of this study is a model of asset management based on Maqashid al-Shariah as a grand theory in shariah stock investments in the capital market, to achieve the ultimate goal of prosperity in the world and the hereafter and provide positive benefits for all parties.
\end{abstract}

Keywords: Islamic wealth management; maqashid al-Shariah

\section{Introduction}

Islamic wealth management is a stimulating subject that has been discussed by scholars. The main topic of their research is related to the theories and principles of some Islamic financial instruments and markets and how these work together, especially for state wealth funds, Islamic wealth management (Basah \& Tahir, 2019; Bello \& Maiyaki, 2013; Omar, 2019). Nevertheless, this study will not elaborate similar topic. The fundamental difference is that this study seeks to develop and find a management model of property management that is in accordance with Islamic teachings on Islamic stock investment in Indonesian capital market. Islamic wealth management practices are based on Islamic values contained in Maqașid al-Shariah as a grand theory in order to achieve the ultimate goal of welfare in the world and in the hereafter (falah) and provide positive benefits (mașlahah) for all parties and prevent negative destructive impacts (mafsadah) (Chapra \& Bank, 2008).

Based on these circumstances, the authors attempted to reconstruct the model through the deconstruction of existing Islamic wealth managementmodels, research on investor actions and thoughts in interpreting Islamic stock investments, management of Islamic stock investment results and aspects of Islamic investment activities by investors at present day. The terminology of deconstruction is different from destructive tendencies. According to Abdullah (2004), deconstruction is interpreted as an effort to requestion established theories that have been built by the mindset of modernism, and then look for and compile theories that are more appropriate in understanding the reality of society today, including diversity, and also the reality of nature. Hence, the deconstruction in this study is an attempt to evaluate and develop the Islamic wealth managementmodel that was once written by the previous researchers.

Ariff and Shamser (2017), explored more theories and principles, by describing some Islamic financial instruments and markets and explaining in what way these works together, especially for wealth funds. However, they have not explained the guidance on how a devout Muslim can manage his wealth to get paid back from time to time in accordance with Maqashid Al-Shariah. On the other hand, Bello and

${ }^{1}$ E-mail: isma.swadjaja@gmail.com

${ }^{2}$ E-mail: tjiptohadi@feb.unair.ac.id

${ }^{3}$ E-mail: unti_ludigdo@yahoo.com 
Maiyaki (2013) conveyed their thoughts on how a Muslim gains wealth through the selection of various Islamic investment instruments such as the Islamic Unit Trust Fund or Islamic Real Estate Investment Trust but have not provided detailed guidance on the process of owning Islamic investment instruments. This was reinforced by the thought of Mokhtar and Ismail (2013) who discussed how a Muslim manages to gain wealth. Yet, they did not provide clear explanation on the permissible forms of wealth creation in Islam without debt, even though the process of possessing property is important to realize the halal and tayibah assets as contained in Maqașid al-Shariah, Ghazali-which focused on safeguarding property (hifz al-mal) and guarding offspring (hifz al-nasl) (Mutiara, Mursinto, \& Maliki, 2019).

The problem of wealth distribution in Islamic wealth managementwas discussed generally and normatively by Ariff and Shamser (2017), Bello and Maiyaki (2013) but they have not clarified about Islamic investment instrument that can be used as an inheritance instrument. In addition, the discussion of inheritance issue was not all attributed to Maqașid al-Shariah as a grand theory which could deepen the discussion on the issue of inheritance. For example, the value contained in Maqașid al-Shariah, namely hifz al-Nasl that discusses the issue of inheritance in terms of the essence of inheritance which aims not to leave the generation or descendants who are economically weak, how are the proportional inheritance distribution and assets that are worthy used as inheritance instruments (hifz al-Mal).

Meanwhile, the discussion on wealth acumulation through Islamic financial instruments have normatively. Still too general and is not associated with Maqașid al-Shariah, such as the development of assets that are beneficial for stakeholders does not explain rational investment behavior instead of emotional, speculation and gambling that can harm other parties and not excessive in developing the treasure. Likewise, the explanation on the use of assets is incomplete and not applicable, it should be discussed the use of assets in accordance with Maqașid al-Shariah as a means of upholding worship to achieve falah namely welfare in the world and in the hereafter (Bello \& Maiyaki, 2013; Omar, 2019).

All stages starting from wealth creation, wealth accumulation, wealth protection, wealth purification and wealth distribution are not associated with the values contained in Maqașid al-Shariah so that it becomes a more applicable guide for muamalah actors in the various fields they are engaged in. In addition, discussions about the aspects of mașlahah were also written separately and were not associated with the implementation of the results of the combination of Islamic wealth management models and Maqașid alShariah even though it is known that the essence of Maqașid al-Shariah's goal is the achievement of Mașlahah and Falah (Bello \& Maiyaki, 2013; Omar, 2019).

The implementation of shariah stock investment in the capital market is part of muamalah activities, so according to Maqashid al-Shariah perspective the whole set of investment activities must be able to provide benefits for investors and stake holders in fulfilling the needs of life in the world and become a means of worshiping Allah SWT (Yazi, 2015; Zandi, Abdul Razak, \& Hidayah Hussin, 2014). The current phenomenon precisely indicates a contradictory situation with the initial purpose of the existence of a capital market which was originally intended to provide benefits for certain parties who need funds for certain purposes that have been approved by the Securities Exchange Commission of Indonesia or used by the public to invest. Cases of behavior deviations that tend to be destructive (mafsadah) in the capital market occur in both the primary market and the secondary market. Based on information disclosure to the public, there have been irregularities in the primary market, namely the misuse of Initial Public Offering funds by issuers, manipulation of issuers' financial statements, information that misleads the public and violations of information disclosure.

In addition, investment behavior deviations also occur in the secondary market, commonly referred to as the unusual market activity based on the disclosured information, it was conveyed that several types of unusual market activity, among others, include failure to pay, bare selling short, cornering, wash trade, indications of insider trading and others (Bikas \& Saponaitè, 2018; Jagongo \& Mutswenje, 2014). One relevant case example is the pseudo trade in shares of PT Sekawan Intipratama Tbk (SIAP) which resulted in a default of around $\mathrm{Rp} 100$ billion. The quasi-transaction actors are based on intentions only to influence or shape the market but there is no transfer of ownership of the shares. This clearly violates the capital market law and is not in accordance with the values contained in Maqashid al-Shariah (Sugianto, 2017).

Various forms of behavioral deviations as mentioned above can lead to not fulfilling expectations of an investment activity or the market becoming anomaly. In these conditions, the theoretical assumptions and conventional financial models that investors always behave rationally in the process of making investment decisions are not always true. Investors are assumed to be willing and able to receive and analyze all available information based on their rationality thinking. Even though in reality investors often show irrational behavior, so this situation deviates from the assumption of rationality and has a bias tendency. At present there appears the theory of financial behavior which aims to investigate the emotional 
characteristics of investors to explain subjective and irrational anomalies in the capital market (Metawa, Hassan, Metawa, \& Safa, 2019; Tauni, Fang, \& Iqbal, 2016).

The Maqașhid al-Shariah based Islamic wealth management model that has a comprehensive dimension in muamalah is suitable for reviewing its application in Islamic stock investment practices in the Indonesian capital market today due to the stock market in the Indonesia Stock Exchange (IDX) has relatively high transaction activities so that financial instruments are often considered to provide big profits. The average daily stock transaction value in 2016 reached 6 trillion, transaction volume of 5.1 billion and frequency of transactions 267 times a day. This situation has resulted in capital market players in the stage of wealth accumulation (investment), which is part of the wealth management process, feeling ambitious to get big profits in a short period of time but tend to forget the negative impact on themselves and others. The ambitious and hasty nature has the potential to cause behavior that justifies any means (irrational) in order to achieve what is possible, as explained in Al-Qur'an Surat Al-Isra' verse 11.

The important things that are deconstructed from the thoughts of the experts include the efforts to obtain wealth only through the selection of Islamic investment instruments without providing guidance on the process of having Islamic investment instruments according to Islamic teachings without going through interest-based debt. Presently, the urgency of the wealth distribution within Islamic wealth management is merely discussed in general and normative but does not explain any Islamic investment instruments that can be used as inheritance instruments. The discussion of the inheritance issue is not at all related to Maqashid al-Shariah as a grand theory that might deepen the discussion on the issue of inheritance. Moreover, wealth acumulation through Islamic financial instruments is still too general and normative and does not associate with Maqashid al-Shariah at all, such as the development of assets that are beneficial for stakeholders. They do not explain rational investment behavior instead of emotional, speculation and gambling that can harm other parties and not excessive in developing these assets. Explanation of how to use assets is also not detailed and applicable, it should be discussed the use of assets in accordance with Maqashid al-Shariah as a means of upholding worship to achieve falah namely welfare in the world and hereafter.

Those general explanation mention the rights of the poor, indeed. Yet, it does not explain the distribution of portions for the poor and clarify the actual actions to fulfill the rights of the poor such as zakat, infaq or alms. Explanation of Islamic wealth management should cover all stages as a whole and not highlight certain stages such as wealth creation and wealth accumulation. All stages starting from wealth creation, wealth accumulation, wealth protection, wealth purification and wealth distribution are not associated with the values contained in Maqashid al-Shariah so that it becomes a more applicable guide for muamalah actors in the various fields they are engaged in. Discussions on aspects of the mashlahah were also written separately and were not associated with the implementation of the results of a combination of Islamic wealth managementmodels and Maqashid al-Shariah. Even though it is known that the essence of the purpose of Maqashid al-Shariah is the attainment of Mashlahah and Falah.

This research aimed at finding a property management model that is in accordance with Islamic teachings in Islamic stock transaction activities in the capital market. The Islamic wealth management process must rely on the guidance of Islamic values contained in Maqashid al-Shariah as a grand theory in order to achieve the ultimate goal of welfare in the world and falah, mashlahah and avoid mafsadah.

\section{Literature Review}

Referring to the theory of Maqashid al-Shariah, Islamic stock investment activities in the capital market are part of muamalah activities, it must contain benefits and not cause damage for all stake holders. Mashlahah in the context of shariah stock trading refers to shariah sources, both Al-Qur'an and hadith. The principles that are intended by various business transactions or muamalah Islam (maqashid al- Shariah fi al-iqtishad). The principles that become the objectives of shariah in this economic field among others are the principle of justice (al-'adalah), the opposite of tyranny (al-zhulm), the principle of honesty and transparency (al-shidq wa al-bayan), the opposite of lies and concealment of facts (al-kidzb wa al-kitman), the principle of asset turnover (al-tadawul) against the accumulation of assets (alkanz), the principle of togetherness, unity and help (al-jama'ah wa alI'tilaf wa al-ta'awun), the opposite of division, strife and contradiction (al-furqah wa al-ikhtilaf wa al-tadabur), the principle gives ease and eliminates difficulties (al-taysir wa raf 'al-haraj al-usri) (Aziz, 2017).

Imam Ghazali (1997), states that Maqashid al-Shariah which focuses on the mashlahah aspect is divided into three categories, namely dharuriyyat, hajiyyat, and tahsiniyyat. He also divided Maqashid alShariah into five, namely guarding religion, soul, mind, lineage and wealth. Those five elements in the Maqashid al-Shariah must be under the auspices of dharuriyyat since they are the safeguarding of cases that must exist for the sake of the establishment of the benefit of religion and the world, where if it does not 
exist then the welfare of the world will not run stable and even will run on damage, chaos and loss of life, in the hereafter will lose safety, enjoyment, and return with a real loss.

In terms of Maqashid al-Shariah as mentioned above, al-Syatibi uses different words namely maqashid Shariah, al-maqashid al-syar'iyyah fi al-Shariah, and maqashid min syar'i al-hukm. Even with different words, according to Bakri (1996), it contains the same goal, namely the purpose of the law revealed by Allah SWT. As al-Syatibi stated: "Indeed, the Shariah is aimed at realizing human welfare in the world and in the hereafter" and "Laws for the benefit of servants". The essence of Maqashid al-Shariah is the benefit of mankind who understand the "attracting benefits and rejecting damage" (jalb al-masalih wa dar 'al-mafasid).

Islamic wealth managementbased on Maqashid al-Shariah is not a normative theory but must be applicable and beneficial to all parties. Quoting the blueprint on the Islamic Fund and Wealth Management that has been produced by the Securities Exchange Commission of Malaysia (2017), to strengthen the implementation of shariah governance in Islamic wealth managementin the capital market, a department or unit that specifically oversees the implementation of the shariah governance must be formed in the capital market. The department or special unit must appoint competent and responsible officers to implement Islamic wealth management. In order to facilitate the operational supervision of Islamic wealth management, it is better to give certain codes transparently to the instrument and the culprit.

The implementation of shariah governance in Islamic wealth managementin the Capital Market depends on external and internal factors. External factors is the external operation of the organization itself that can either be listed companies or non-listed entities. It is also can be considered the regulatory phase where the researchers look at the operation and organization structure of the Islamic capital market itself under the curfew of the Security Commission Malaysia or SCM. Internal factors is the internal operation of the organization itself. Depends on the organization's structure and operation, the existence of Shariah governance is entirely flexible. This is depended on their establishment (the Memorandum of Association and Articles of Association), the BOD and the management themselves. Zain (2017) states that the legal awareness and understanding of the top management of the organization can influence their decision making. Their decision making as the leadership of the organization may directly or indirectly lead to the change of culture and practices of their staffs.

\section{Research Method}

This research was conducted using qualitative methods through the postmodernism approach. The origin of the birth of postmodernism cannot be separated from the existence of modernism. Postmodernism arises due to the failure of modernism in uplifting human dignity and as a form of protest against the perceived lack of expression in the flow of modernism. For postmodernism, modernism is considered to have failed in keeping its promises to bring a better and no violence human life. One of the most important characteristics of the postmodernism approach is deconstruction. According to Abdullah (2004), deconstruction is interpreted as an effort to re-question established theories that have been built by the mindset of modernism, and then look for and compile theories that are more appropriate in understanding the reality of society today, including diversity, and also natural reality. Thus, the deconstruction in the context of this research is an effort to evaluate and develop the Islamic wealth management model that was written by previous researchers.

The researchers chose the postmodernism approach developed by Flaskas (2002), and Abdullah (2004) who had conformity with the objectives and character of this study. This research was conducted by textual deconstruction of the thoughts of Ariff and Shamser (2017), Bello and Maiyaki (2013), Mokhtar and Ismail (2013), Nurizal (2016), and (Omar, 2019), about Islamic wealth management model in the current context of shariah stock investing in the Indonesian capital market.

\section{Data Collection Technique}

The research informants were divided into two namely key informants and supporting informants as a tool to verify the validity of the data (Triangulation) in this research. The informants in this research were twenty-five people consisting of sixteen key informants and nine supporting informants. Key informants and supporting informants came from three securities companies. The data collection was carried out through some techniques or procedures, among other were unstructured interviews, participatory observation of all informants who were subject to shariah share investment and management of stock investment results shariah in established research locations and study of documentation to support data effectiveness and efficiency. 


\section{Result and Discussion}

In the perspective of Islamic wealth management, the transfer of shariah share ownership occurs at the stage of wealth creation, therefore the aspect that must be protected according to the Maqashid alShariah guidelines is the halal and "shariah shares" according to shariah principles by fulfilling the elements of religious care (hifz al-din) and treasure care (hifz al-mal), the mechanism of purchase and rational buying behavior based on science (hifz al-'aql) and can control themselves not to excessive in seeking profit in buying and selling (hifz al-nafs). Currently, investors possibly obtain shariah shares through buying transactions, inheritance or employ stock option program (ESOP) from the issuer, through the process of grants as well as corporate action results, namely bonus shares and Pre-emptive Rights (Right Issue) carried out by the issuer.

The above description can be justified according to the rules of muamalah fiqh for it includes the type of ikhtiyary, namely the transfer of property takes place not by itself but through reciprocal agreements between two or several parties in buying and selling unilateral will in grants and gifts. Meanwhile the effort to obtain shariah shares from inheritance or grants from parents or relatives of informants is justified according to the rules of muamalah fiqh. This is called as ijbary or the process of asset transfer that takes place by itself which anyone cannot refuse (Haji Besar, Abd Sukor, Abdul Muthalib, \& Gunawa, 2009; Safiullah \& Shamsuddin, 2018).

The purpose of Modernism thinking concerning investment motivation that develops presently is seeking for income. While the difference of postmodernism thinking is not stagnant there, but it continually seeks differences towards the novelty and perfection in pursuing shariah. Through unstructured interviews, researchers found that the motivation of informants to invest in Islamic stocks in a massive manner still leads to the worldly profit of the individual perpetrators, such as developing knowledge, seeking profits, seeking other income, and some even just fad or speculation. From the results of the study it was found that the informants' motives for perfecting muamalah according to shariah were still relatively small, this also showed that the commitment of most of the other informants was still not serious in carrying out the teachings of Islam in total (kaffah). Shariah is only upright for matters of ritual worship but it has not touched on the muamalah aspects carried out by the informants.

In modernism, the concept of leverage in business practice means an effort to maximize profits through debt to other parties both institutions and individuals. It is contradictory to postmodernism that does not recommend debt as a habit in muamalah. The findings of the data during the study in the context of investment in shariah shares are totally prohibited to owe both the debt of the stock (short selling) and debt money (margin trading). The basic consideration is that debt has many disadvantages compared to the problem for the perpetrator because the debt in the stock investment (margin trading) is containing usury which is prohibited in Islamic teachings.

Wealth accumulation through Islamic stock investment, according to modernism perspective, focuses on efforts to multiply the shares and or money from the investment. While postmodernism initiated the concept of perfection of shariah muamalah so that the main goal of looking for assets is not only the amount in terms of quantity but more important is the value of blessing. The definition of the word blessing is "God's gift that brings good to human life". Postmodernism concept of contemporary scholars also explains the meaning of blessing as everything that is abundant and rich, including material and spiritual blessings, such as safety, tranquility, health, wealth, children, and age.

The thought of modernism that has become public opinion today about stock investment is identical to short-term transactions (time horizon) to pursue capital gains. The orientation of short-term transactions is not always incorrect as long as the perpetrators are not trapped in the arena of speculation and gambling (maysir) without relevant scientific basis. However, referring to postmodernism, the single universalization must be shifted towards a dynamic according to developments into a mixed portfolio strategy, namely a combination of short- and long-term strategies. The depth meaning is that informants who are oriented only in the short term, although allowed but often stuck in the speculation (maysir) which is not justified syar'i and for long-term oriented informants, there are benefits in it such as profit sharing in the form of dividends and shares as an inheritance instrument.

The results of participatory observation showed that the alternative meanings of the diversity of dynamic thinking which is a feature of postmodernism is the pattern of management of the results of shariah stock investments conducted by informants. The diversity can be classified, first is the informant who deposits investment proceeds in the form of diversifying Islamic stock portfolios with different industrial sectors, second is the informant who keeps investment funds into well-esteemed companies and is suitable for holding in long period of time. This type of stock can be used as an inheritance instrument and third is an informant who stores investment funds in banks in the form of savings and time deposits. The point is that even though the investment process is in accordance with shariah, the management of the results of 
transactions in the form of deposits still does not meet the Shariah element. Most of informants keep the Islamic stock investment proceeds in a conventional bank.

Another characteristic of postmodernism is the concept of irony. In general, irony is intended as a way to show that something is contrary to what was previously thought. The event that is expected to occur but is not as expected and becomes a fate. The process of asset management in the stage of wealth generation might generate effects beyond the expectations of the culprit such as losses or even bankruptcy. However, if at that stage the perpetrators are oriented towards the value of Maqașid al-Shariah, namely hifz ad-din and hifz an-nafs, then the attitude of patience, gratitude and trust will arise for what Allah SWT has given the shariah stock investment actors (Maskuroh, 2014).

The researchers found that only a small proportion of shariah stock investors did wealth purification through zakat, infaq and sadaaqah from the results of their investments. Some informants made zakat, infaq and sadaaqah payments after being combined with other income. On the other hand, there are informants who have not at all thought to set aside the results of Islamic stock investments to pay zakat, infaq and sadaaqah payments. This showed the low level of awareness of investors to conduct wealth purification through zakat, infaq and alms from the results of their investments.

According to the postmodernism perspective, insurance is not the only option to protect and deal with the risks that arise. There are still other options that can be used in wealth Protection. These options include hedging, utilizing other financial products, such as futures contracts, forward, swap, option and appropriate diversification the risks faced by overall wealth can be minimized (Tandelilin, 2010).

In Islamic wealth management, inheritance themes are included in the stage of wealth distribution (Basah \& Tahir, 2019). Things that must be considered and maintained in the stage of Islamic wealth distribution are mechanisms for the distribution of inheritance and assets or instruments that can be inherited to the next generation. The discussion about the problem of inheritance in the modern era, of course, identically with inheriting property from parents to children or their heirs in the form of land, houses, gold, money and other valuable physical items. The discontinuity of thinking that has been entrenched occurs in postmodernism thinking today, namely along with the development of the era, assets that can be inherited are not only limited to actual land or assets, but securities such as shariah shares can be used as inheritance instruments.

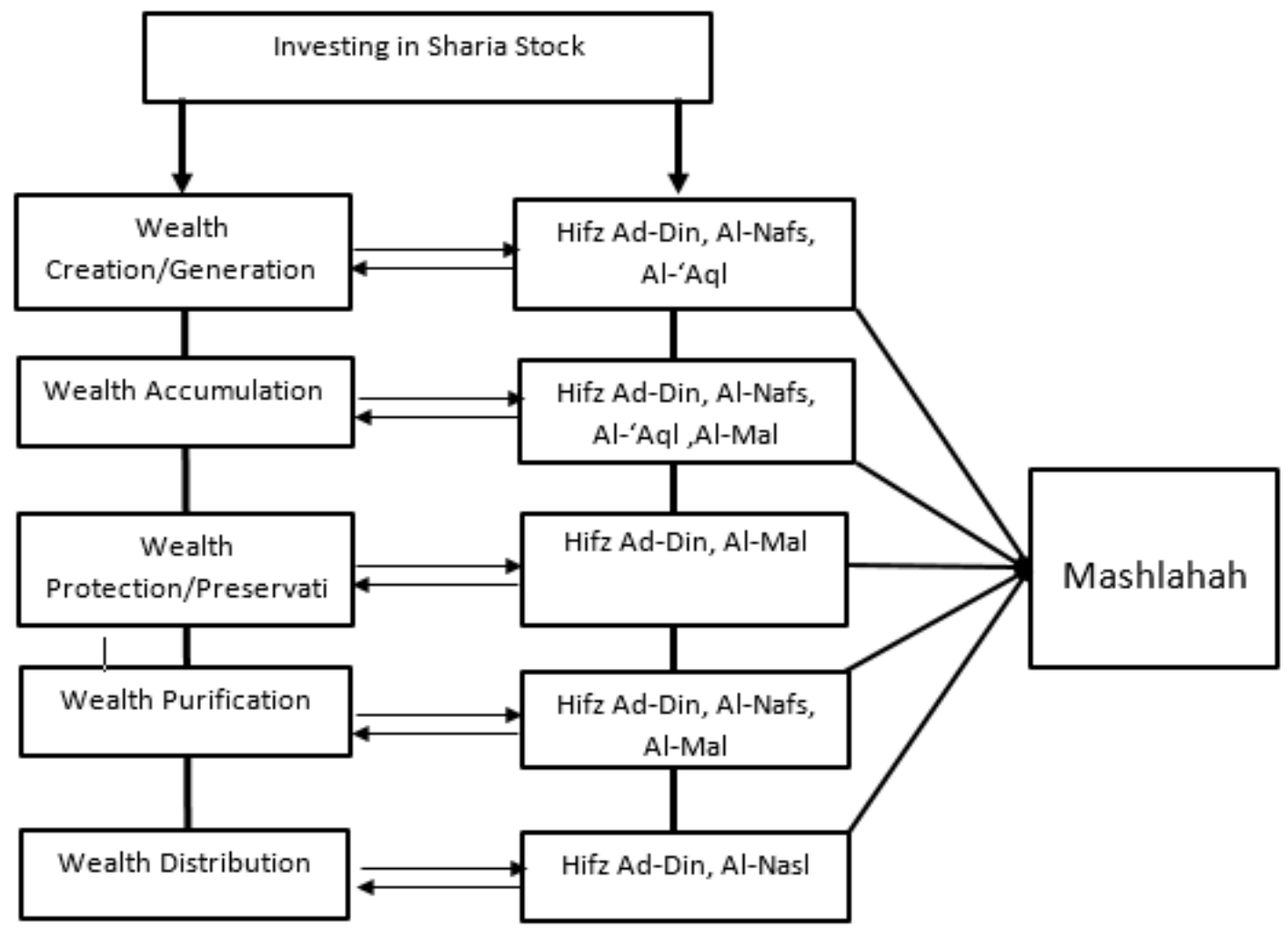

Figure 1. Islamic wealth management based on maqashid al-Shariah 
Based on the result of discussion above, Figure 1 present the construct of the Islamic wealth management model based on Maqashid al-Shariah which is a combination of two theories namely interrelated Islamic wealth management and Maqashid al-Shariah where each stage of Islamic wealth management begins from wealth generation/creation, wealth accumulation, protection/preservation wealth, wealth purification to wealth distribution must be oriented to one or several of the five relevant points in the Maqashid al-Shariah, among others: hifz ad-din, hifz al-nafs, hifz al-'aql, hifz al-nasl, hifz al-mal.

The above model briefly described that investors who initiate shariah share transactions means entering the wealth creation stage oriented to 3 (three) main points of Maqashid al-Shariah. At this stage in syar'i, it is regulated that in order to obtain halal property or money must be in a halal manner (hifz ad-din), not detrimental to the soul (hifz an-nafs) and damage the mind or be accepted in a common sense (hifz al 'aql), i.e. investors can buy Islamic stocks without debt, obtain shariah shares through inheritance or employ stock option program (ESOP) from the issuer, through the process of grants and corporate action.

Continuous purchase of Islamic shares through the Indonesia Stock Exchange (IDX) is a wealth accumulation activity that must be oriented towards hifz ad-din, hifz al-nafs, hifz al-'aql and hifz al-mal. This is done to avoid the irregularities of shariah share transactions by hoarding, speculating, ambitious to gain profits in the short term and sometimes irrational which can harm others. Most investors who gain profits often fail to manage their cash flow because most of the profits from the earnings are put in to transact with motives to get even greater profits. Therefore, at this stage investors should do wealth preservation in various ways that are in accordance with the values in the Maqashid al-Shariah (hifz ad-din, hifz al-mal), such as following a shariah insurance program, buying productive assets, diversifying Islamic stock portfolios, saving in Islamic banks, and so on.

In postmodernism, wealth management must add the stage of wealth purification of assets and souls in accordance with the values of Maqashid al-Shariah (hifz ad-din, hifz al-nafs and hifz al-mal) for the investment benefits obtained by these investors. It does not mean that the assets obtained through illegitimate ways can be sanctified in Islam, but issue the parts of the property which may be the provision of other people who are entrusted through our efforts. As the word of God in the Qur'an the letter AdzDzariyaat verse 19:

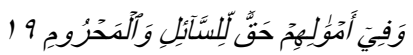

"And on their possessions, there are rights for the poor who ask and the poor who don't ask (because they maintain their honor)".

Furthermore, the final stage (wealth distribution) is still rarely done by most investors, namely making Islamic shares owned as inheritance. Based on regulations in the capital market, Islamic stocks can now be used as assets that can be inherited to heirs. The process of wealth distribution oriented hifz ad-din and hifz al-nasl, meaning that an investor who conducts shariah share transactions must have a long-term plan (long term investment). This can be realized through the purchase of certain Islamic stocks that meet the qualifications to be used as inheritance instruments. The five stages in Islamic wealth management that have fulfilled the core values in the Maqashid al-Shariah mentioned above are expected to obtain mashlahah and become a means of achieving prosperity in the world and hereafter.

\section{Conclusions, suggestions and limitations}

Islamic based Wealth Management Model can be used as a guide and as a controlling tool for informants in conducting investment activities and managing Islamic stock investment results in the capital market in order to increase perfection in muamalah according to Islamic law. The actions and thoughts of most of the informants in interpreting Islamic stock investments have not fully reflected the procedures that are determined according to Islamic law. The management of Islamic stock investment proceeds made by informants at this time has not met the expectations of Islamic wealth management theory.

It was revealed from the findings that informants have not saved the results of their investments in Islamic banks. Emotional control at the time of reinvestment results in profits is still low because it is driven by greed ambitions to get even greater profits. Likewise, informants made disfellowshipping measures for the results of their investments and awareness about wealth distribution oriented to hifz al-Nasl is still low, namely long-term oriented for the purpose of obtaining profit sharing from the company in the form of dividends and shares as inheritance instruments. Besides, debt purchases can burden the heirs. The attitude and behavior of investors in investing in shariah shares must be changed, namely from a hurry, emotional attitude, complaining towards an ideal attitude of a Muslim and a believer who has a patient, calm, rational attitude, trusts and is grateful for whatever the investment endeavors. Islamic stock investors have obtained financial and non-financial problems, however, only a few of investors have linked the aspects of benefit 
with peace of mind (hifz an-nafs), intention to perfect muamalah according to shariah (hifz ad-din), seeking blessings and welfare in the hereafter (hifz al-mal).

Based on conclusions, the implications of the results of the study, the limitations of the study and for the development of further research, the following suggestions were conveyed that Islamic stock investors are advised to be able to change and combine the composition of shariah stock portfolios for inheritance interests. Shariah stock investors are deemed necessary to have a patient, grateful and trustworthy attitude in investing in shariah shares so as to practice Islamic investment behavior. Shariah stock investors are expected to be able to disburse their investment proceeds so that they can be rewarded in assets acquired through Islamic stock investments in the capital market. The values contained in the Islamic wealth management model based on maqashid al-Shariah must be continuously socialized to all shariah stock investment actors in the capital market as a guide in managing the management and organization of assets in accordance with Islamic law. Further, to establish a specific department or unit under their supervision for Islamic wealth management and services. This is necessary for proper supervision and control over any issues relating to Islamic wealth management.

The limitations of this study were the difficulties to get non-Muslim informants who invest in shariah stocks so that they are expected to provide an assessment from a different perspective on the Maqashid alShariah-based Islamic wealth management model in the capital market. Additionally, researchers have not screened the level of understanding of informants on the teachings of Islam in the muamalah aspect so that information that was explored related to the intention of investors in investing and management of investment results in shariah shares has not been as deep as expected by researchers.

\section{Acknowledgments}

We would like to thank the fishermen community in Padang Pariaman District for being willing to answer the questionnaire. We also thank the Community Research and Development Institute of Andalas University for providing assistance, so that this research can contribute to others.

\section{References}

Abdullah, Amin. (2004). Kalam philosophy in the era of postmodernism, Student Library, Yogyakarta.

Al-Ghazali, Al-Mustasfa. (1997). Juz I, Bairut: Daar al-Ihya 'al Turas al-abyAraby, p. 217.

Al-Jauza, http://www.scribd.com/doc/27492923/5-Theory- Postmodernism. Uploaded on Saturday, May 23, 2018.

Ariff and Shamser. (2017). Islamic wealth management: Theory and Practice. Journal of Islamic Studies, Volume 30, Issue 2, May 2019, Pages 293-297, https://doi.org/10.1093/jis/ety047.

Aziz, M. (2017). Perspektif Maqashid Al-Shariah dalam Penyelenggaraan Jaminan Produk Halal di Indonesia Pasca Berlakunya Undang - Undang Nomor 33 Tahun 2014 Tentang Jaminan Produk Halal. Al Hikmah.

Bakri, Asafri Jaya.(1996). Maqashid Shariah According to Al-Syatibi, Jakarta: PT Raja Grafindo Persada.

Basah, S., \& Tahir, P. R. (2019). Towards Acceptance of Islamic Wealth, 4(24), 14-41.

Bello, G. B., \& Maiyaki, A. A. (2013). Readings in Islamic Banking and Finance. IIIBF. Retrieved from https://books.google.co.id/books?id=0nCKrgEACAAJ

Bikas, E., \& Saponaite, V. (2018). Behavior of the Lithuanian investors at the period of economic growth. Entrepreneurship and Sustainability Issues. https://doi.org/10.9770/jesi.2018.6.1(4)

Chapra, M. U., \& Bank, I. D. (2008). The Islamic Vision of Development in the Light of the Maq $\bar{a}$ sid AlSharī'ah. Jeddah.

Haji Besar, M. H. A., Abd Sukor, M. E., Abdul Muthalib, N., \& Gunawa, A. Y. (2009). The Practice of Shariah Review as Undertaken by Islamic Banking Sector in Malaysia. International Review of Business Research Papers.

Jagongo, A., \& Mutswenje, V. S. (2014). A Survey of the Factors Influencing Investment Decisions : The Case of Individual Investors at the NSE. International Journal of Humanities and Social Science.

Maskuroh, E. (2014). Kinerja Bank Shariah dan Konvensional di Indonesia. Justicia Islamica, 11(2), 187218.

Metawa, N., Hassan, M. K., Metawa, S., \& Safa, M. F. (2019). Impact of behavioral factors on investors' financial decisions: case of the Egyptian stock market. International Journal of Islamic and Middle Eastern Finance and Management. https://doi.org/10.1108/IMEFM-12-2017-0333

Mutiara, N., Mursinto, D., \& Maliki, Z. (2019). Community Participation in Village Development from Islamic Economic Perspectives. Journal of Innovation in Business and Economics, 3(01), 23-32. https://doi.org/10.22219/jibe.v3i01.7350 
Omar, F. M. (2019). Inequality, concentration of wealth and ownership structure of Islamic banks: Some pertinent issues. International Journal of Ethics and Systems, 35(3), 444-465. https://doi.org/10.1108/IJOES-11-2018-0155

Safiullah, M., \& Shamsuddin, A. (2018). Risk in Islamic banking and corporate governance. Pacific Basin Finance Journal. https://doi.org/10.1016/j.pacfin.2017.12.008

Sugianto, D. (2017). Manajemen Sekawan: Kami Mohon Suspensi Saham Dibuka. Retrieved June 12, 2019, from https://finance.detik.com/bursa-dan-valas/d-3728342/manajemen-sekawan-kamimohon-suspensi-saham-dibuka

Tauni, M. Z., Fang, H. X., \& Iqbal, A. (2016). Information sources and trading behavior: does investor personality matter? Qualitative Research in Financial Markets. https://doi.org/10.1108/QRFM-082015-0031

Yazi, E. (2015). The Effects of Shariah Compliance Announcement towards Stock Price Changes in Malaysia. Journal of Economics, Business and Management, 3(11). https://doi.org/10.7763/JOEBM.2015.V3.327

Zandi, G., Abdul Razak, D., \& Hidayah Hussin, N. (2014). Stock Market Screening: An Analogical Study on Conventional and Shariah-Compliant Stock Markets. Asian Social Science, 10(22). https://doi.org/10.5539/ass.v10n22p270 
